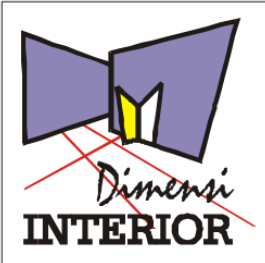

http://dimensiinterior.petra.ac.id

\title{
Studi Ikonografi Panofsky Pada Ornamen Interior Vihara Avalokitesvara Pamekasan, Madura
}

\author{
Felicia Tania | Lintu Tulistyantoro | Linggajaya Suryanata \\ Program Studi Desain Interior, Universitas Kristen Petra, Surabaya \\ Email: feliciatania1510@gmail.com
}

\begin{abstract}
ABSTRAK
Vihara Avalokitesvara Pamekasan, Madura merupakan Vihara yang dibangun pada 300 tahun yang lalu. Vihara ini merupakan peninggalan kerajaan Majapahit yang berhasil bertahan hingga hari ini dan menjadi salah satu Vihara yang megah di Indonesia. Hal yang menarik dari Vihara ini adalah bahwa Vihara ini bukan hanya menjadi tempat ibadah bagi pemeluk agama Buddha, Khonghucu, maupun Tao tetapi juga menjadi tempat ibadah bagi pemeluk agama Islam dan Hindu. Perkembangan Vihara ini menjadikan Vihara ini menarik untuk dikaji makna-makna ornamen yang terkandung didalamnya. Untuk mengkaji pemaknaanya digunakan metode studi ikonologi yang dikemukakan oleh Panofsky. Metode ini dilakukan dengan tahapan deskripsi pra ikonografi, tahapan analisis ikonografi dan tahapan interpretasi ikonologi. Tahap pra-ikonografi dilakukan sebagai langkah awal untuk menemukan makna primer. Sedangkan tahap ikonografi dilakukan sebagai langkah lanjutan untuk menemukan makna sekunder dan tahap interpretasi ikonologi untuk menemukan makna intrinsic. Makna primer yang dihasilkan dari tahap pra- ikonografi menunjukkan wujud dari ragam hias ornamen pada interior Vihara Avalokitesvara. Adapun tahap ikonografi menghasilkan makna sekunder yang menunjukkan bahwa makna ragam hias ornamen pada interior Vihara mengandung makna filosofis kebudayaan China dan ajaran Buddha. Selanjutnya makna bangunan diinterpretasikan berdasarkan kondisi politik, sosial, dan budaya Indonesia selama orde lama hingga saat ini.
\end{abstract}

Kata Kunci: ikonografi, interior, ornamen, Panofsky.

\section{ABSTRACT}

Vihara Avalokitesvara Pamekasan, Madura is a monastery built in 300 years ago. This monastery is a relic of the Majapahit kingdom that has survived to this day and become one of the magnificent temples in Indonesia. The interesting thing about this monastery is that this temple is not only a place of worship for Buddhists, Confucians, or Taoists but also a place of worship for Muslims and Hindus. The development of this monastery makes the Vihara interesting to study the meaning of the ornaments contained therein. To study the use of the method of astronomical studies proposed by Panofsky. This method is done by the description stages of pre-iconography, the stages of iconographic analysis and the stages of iconological interpretation. The preiconography stage is performed as a first step to finding the primary meaning. The second stage is to find the meaning of secondary and the stage of iconological interpretation to find intrinsic meaning. The primary meaning resulting from the preiconography stage shows the form of decorative ornaments in the interior of Avalokitesvara Vihara. The iconography stage produces a secondary meaning indicating that the meaning of decorative ornaments on the interior of the Temple contains the philosophical meaning of Chinese culture and Buddhism. Furthermore, the meaning of the building is interpreted based on the political, social, and cultural conditions of Indonesia during the old order to the present.

Keywords: iconography, interior, ornament, Panofsky.

\section{PENDAHULUAN}

Etnis Tionghoa masuk ke Indonesia dengan membawa gama seperti Buddha, Tao, dan Khonghucu [1]. Keberadaan agama-agama ini mendorong adanya Vihara di Indonesia sejak tahun 1650. Perjalanan panjang Vihara di Indonesia tidaklah mudah. Terdapat berbagai tindak diskriminatif terhadap etnis Tionghoa. Terlebih pada pemerintahan Soeharto, beliau mengeluarkan Inpres No.14 Tahun 1967. Dalam peraturan tersebut menyebutkan bahwa agama yang dianut oleh etnis
Tionghoa (Khonghucu) beserta hal-hal yang berkaitan dengan perayaan-perayaan hari besar seperti Imlek dilarang ditampilkan di depan umum dan hanya boleh dilakukan secara intern saja [2]. Akibat kebijakan pemerintah tersebut, kebudayaan Tionghoa di Indonesia menjadi lumpuh. Bahkan hal ini mempengaruhi fisik bangunan klenteng atau vihara.Pembangunan dan renovasi dilakukan secara diam-diam atau sembunyisembunyi [2]. Namun, setelah masa orde baru tersebut keadaan mengalami perbaikan bagi masyarakat Tionghoa 
pada masa reformasi. Di bawah kepemimpinan Presiden K.H. Abdurahmanwahid beberapa kebijakan yang bersifat diskriminatif terhadap etnis Tionghoa di hapuskan.Bahkan pada masa pemerintahan Presiden Susilo Bambang Yudhoyono, diskriminasi semakin memudar, lebih terbuka dan bebas.Hal tersebut diteguhkan dalam UU No.40/2008 tentang Penghapusan Diskriminasi Ras dan Etnis (PDRE).

Di samping diskriminasi-diskriminasi tersebut, terdapat fakta bahwa agama Islam menjadi identitas dan agama yang utama di Madura [3], namun ditengah fakta yang sedemikian rupa masyarakat sekitar mampu menjalankan kehidupan agamanya bersama-sama secara damai dan mampu menerima keberadaan Vihara tersebut.

Di tengah berbagai diskriminasi terhadap etnis Tionghoa, Vihara mampu mempersatukan dalam satu kesatuan dengan mendirikan mushola, pendopo pagelaran wayang, dan pura didalam Vihara tersebut. Adanya semuanya itu merupakan hasil dari perjalanan yang panjang.pada mulanya Vihara ini merupakan tempat sembahyang keluarga pada masa kolonial Belanda di abad 17-an. Mereka menemukan sebuah patung wanita yang dipercayai sebagai Dewi Kwan Im. Namun ternyata patung tersebut adalah patung peninggalan kerajaan Majapahit.Patung tersebut adalah patung pendharmaan Ratu Majapahit Tribhuwanatunggadewi. Majapahit merupakan kerajaan yang bercorak Siwa-Buddha yang mempercayai adanya kultus dewa raja [4].

Dari segi interior maupun arsitektur, hal yang menarik adalah dilihat dari segi budaya adalah dengan adanya pengadopsian budaya selain budaya China seperti adanya bangunan seperti miniatur candi yang mengadopsi dari Candi Borobudur dan penggunaan ornamen dari kebudayaan Jawa. Setelah melihat latar belakang kondisi Indonesia yang cukup sulit untuk mendukung Vihara ini bisa bertahan dan berkembang serta berbagai keunikan di dalam Vihara ini menjadikan Vihara ini menarik untuk dibahas dalam melalui pendekatan ikonografi.

Ikonografi yang digunakan adalah ikonografi Panofsky yang merupakan metode untuk mencari makna yang terkandung dalam suatu karya seni sekaligus mengetahui latar belakang sosial, budaya, dan politik dari suatu karya seni yang mempengaruhi terciptanya karya seni tersebut [5].

Tujuan penelitian ini adalah untuk mengetahui makna ornamen interior Vihara berdasarkan metode ikonografi Panofsky.Batasan dalam penelitian ini adalah ornamen pada area ruang sembahyang utama (Kwan Im Thang), Pendopo, Gedung Dhamasala, dan gedung altar Thian Kong. Pembatasan didasarkan kepada satu kesatuan layout ruang sembahyang utama (Kwan Im Thang), Pendopo, dan gedung altar Thian Kong serta urutan tata cara sembahyang dalam Vihara Avalokitesvara dan yang terakhir didasarkan pada keberagaman ornamen yang terdapat pada gedung tersebut. Penelitian ini masuk kepada penelitian kualitatif yang bersifat deskriptif. Pengumpulan data dilakukan dengan melakukan observasi, wawancara, dan dokumentasi (lihat gambar 1)

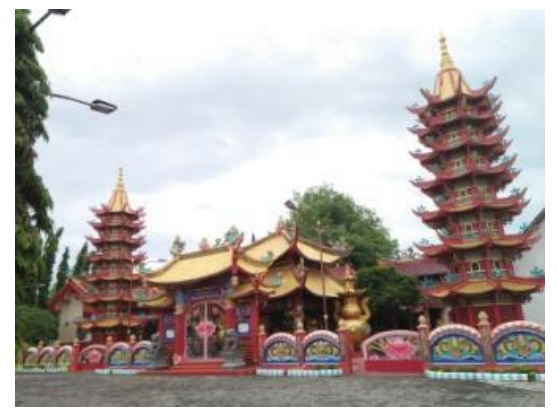

Gambar 1. Dokumentasi Bangunan Vihara Avalokitesvara Pamekasan, Madura

\section{METODE KAJIAN IKONOGRAFI}

Studi ikonografi Panofsky merupakan suatu metode penelitian yang digunakan untuk mencari makna yang terkandung dalam suatu karya seni sekaligus mengetahui latar belakang sosial, budaya, dan politik dari suatu karya seni yang mempengaruhi terciptanya karya seni tersebut. Pencarian makna dilakukan melalui tiga tahapan yaitu, pertama adalah tahap pra ikonografi, kedua adalah tahap analisa ikonografi dan tahap ketiga adalah tahap interpretasi ikonologi. [5]. Berikut tahapan kajiannya:

Pada tahap pertama atau tahap pra ikonografi, tahapan ini merupakan tahapan pembahasan pemaknaan primer atau pemaknaan tingkat satu dimana pemaknaannya bersifat tekstual atau secara harafiah. Tahapan ini di bagi lagi menjadi dua tahap yaitu faktual dan ekspresional. Tahapan faktual adalah tahapan yang mendeskripsikan objek yang terlihat secara visual, sedangkan tahap ekspresional adalah tahapan yang mendeskripsikan empati dari kemampuan mengamati kebiasaan dan rasa familier terhadap objek dan peristiwa.Tahap pra ikonografi mengkaji mengenai bentuk, warna, ukuran, tekstur, posisi, dan material. Pada tahap ikonografi ini, alat pemaknaan yang dibutuhkan adalah pengalaman praktis dengan prinsip korektif sejarah gaya atau history of style.

Tahap kedua atau tahap analisa ikonografi adalah tahapan dimana obyek yang dianalisa merupakan obyek yang tidak terlihat secara visual dan merupakan pemaknaan sekunder. Pemaknaan pada tahap ini merupakan kelanjutan pembacaan arti dari aspek-aspek tekstual sebelumnya yang melalui tahap ini dihubungkan dengan tema dan konsep. Obyek yang akan dianalisa adalah makna tanda, simbol, ikon, atau motif suatu objek secara literal. Alat pemaknaan yang dibutuhkan adalah pengetahuan tentang sumber literal dan prinsip korektifnya mengacu pada sejarah tipe-tipe/ history of types.

Tahapan terakhir atau tahap interpretasi ikonologi merupakan tahap yang membedakan ikonografi dengan semiotika.Pada tahapan ini merupakan tahapan pengungkapan makna intrinsik atau isi, dengan menyusun nilai "simbolis" dari intuisi sintesis dan sejarah kebudayaan yang terjadi dalam lingkup karya seni. Tahap interpretasi mengkaji keterkaitan karya seni dengan latar belakang pencipta karya,kondisi politik-sosial-budaya pada masa penciptaan karya seni. Alat yang digunakan untuk pemaknaan adalah intuisi sintetis dan prinsip korektif yang digunakan adalah sejarah gejala kultural. 


\section{HASIL DAN PEMBAHASAN}

Vihara Avalokitesvara Pamekasan, Madura terdiri dari beberapa massa bangunan, diantaranya: area altar sembahyang Thian Kong (area A pada layout), pendopo (area B pada layout), ruang Kwan Im Thang atau ruang sembahyang utama (area C pada layout), ruang Dhamasala (area D pada layout), gedung agung (area E pada layout), ruang Lithang (area F pada layout), area administrasi (area G pada layout), pura (area $\mathrm{H}$ pada layout), dan kuti (area I pada layout). Secara umum, terlihat dari layout bangunan-bangunan yang ada pada vihara Avalokitesvara Pamekasan, Madura memiliki bentuk geometris. (lihat gambar 2)

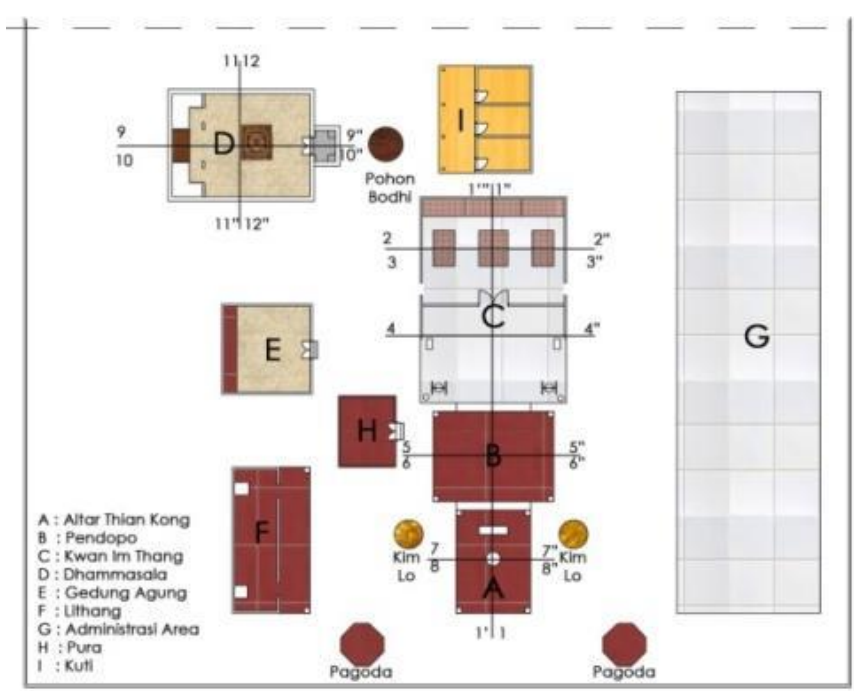

Gambar 2. Layout Vihara Avalokitesvara Pamekasan, Madura

Pada gedung ruang sembahyang utama, pendopo, dhamasala, dan gedung altar Thian Kongakan dilakukan analisa sesuai tahapan ikonografi tahap pertama dan tahap kedua. Selanjutnya bangunan secara keseluruhan akan diinterpretasi secara keseluruhan sesuai tahap ketiga yaitu interpretasi ikonologi.

\section{A. Ruang Sembahyang Utama (Kwan Im Thang)}

Ruang ini merupakan ruang yang ada pertama kali di dalam Vihara ini. Ruang ini direnovasi untuk yang pertama kali pada tahun 1951 karena rusak akibat agresi militer Belanda. Di dalam ruang inilah dapat ditemukan patung peninggalan Majapahit. (lihat gambar 3)
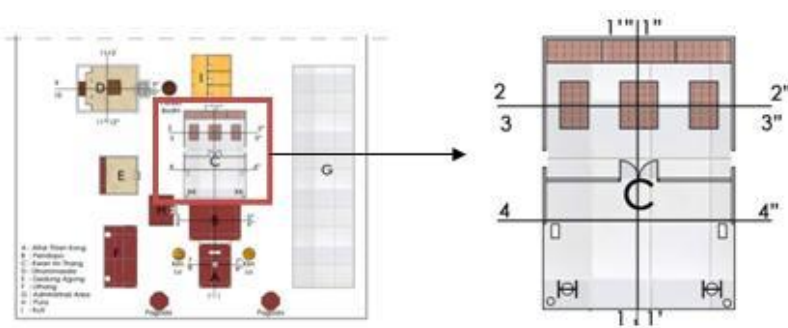

Gambar 3. Layout Vihara Avalokitesvara Pamekasan, Madura (kiri) dan layout ruang sembahyang utama (kanan).

Ruang sembahyang utama terletak di belakang area pendopo dan area altar Thian Kong. Ruang ini berbentuk geometris persegi panjang dan dapat terlihat pada penataan ruangnya bahwa ruang ini bersifat simetris. Orientasi ruang menghadap ke selatan (lihat gambar 4)

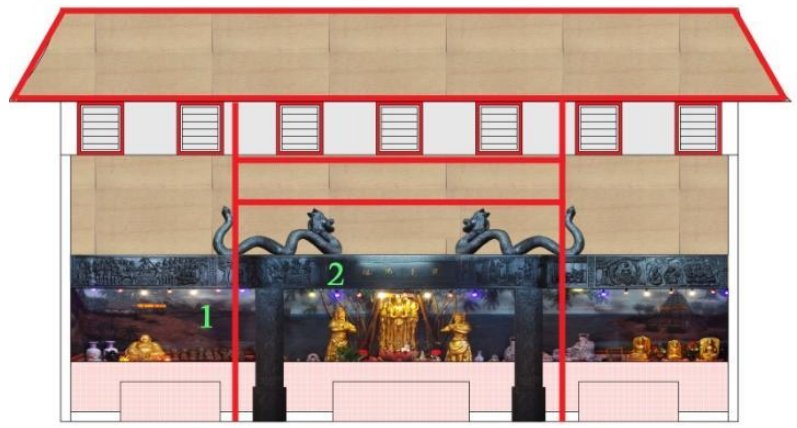

Gambar 4. Tampak potongan 2-2", area altar sembahyang dengan relief dan partisi

Berikut tabel analisa dinding pada Ruang Sembayang Utama (lihat tabel 1)

Table 1. Analisa ornamen pada dinding ruang sembahyang utama.

\begin{tabular}{|c|c|c|}
\hline Ornamen & Tahap Pra-Ikonografi & Tahap Analisa Ikonografi \\
\hline $\begin{array}{l}\text { 1. Relief } \\
\text { mences }\end{array}$ & 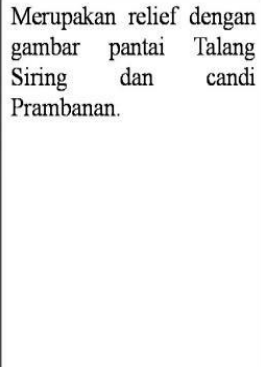 & $\begin{array}{l}\text { Pantai Talang Siring } \\
\text { adalah area dimana } \\
\text { patung Dewi Kwan Im } \\
\text { dan Sam Po Hud } \\
\text { ditemukan (Personal } \\
\text { conversation, Februari 2, } \\
\text { 2017). Sedangkan Candi } \\
\text { Prambanan merupakan } \\
\text { candi peninggalan agama } \\
\text { Hindu dari Mataram kuno } \\
\text { pada tahun 856 (Magical } \\
\text { Prambanan 18) }\end{array}$ \\
\hline
\end{tabular}

Berikut tabel analisa partisi pada Ruang Sembayang Utama (lihat tabel 2)

Table 2. Analisa ornamen pada partisi ruang sembahyang utama.

\begin{tabular}{|c|c|c|}
\hline Ornamen & Tahap Pra-Ikonografi & Tahap Analisa Ikonografi \\
\hline $\begin{array}{l}\text { 2. Relief, Kaligrafi dan } \\
\text { Naga } \\
\text { a. Buddha Gautama } \\
\text { mengajar } \\
\text { b. Sulur dan Swastika } \\
\text { c. Kaligrafi dan naga }\end{array}$ & \begin{tabular}{|} 
Terdapat relief sang Buddha \\
Gautama sedang mengajar \\
pada samping kanan dan \\
kiri,serta swastika, sulur dan \\
teratai pada bagian partisi \\
yang berdiri secara vertikal. \\
Di bagian tengah terdapat \\
kaligrafi china 祖佛音觀dan \\
diatas kaligrafi & tersebut \\
terdapat ornamen naga yang \\
merupakan naga & Jawa. \\
Partisi & tersebut \\
bermaterialkan kayu dengan \\
finishing varnish, memiliki \\
warna cokelat tua yang pekat
\end{tabular} & $\begin{array}{l}\text {-Sulur merupakan lambang } \\
\text { keabadian dan kemakmuran } \\
\text { (Wen 53). } \\
\text {-Swastika dalam ajaran } \\
\text { Buddha menandakan } \\
\text { keberuntungan dan nasib } \\
\text { baik serta jejak kaki Buddha } \\
\text { dan jantung Buddha (Herlina } \\
\text { 19). } \\
\text { Teratai merupakan lambang } \\
\text { kemurnian dan juga hasil } \\
\text { baik (Williams 9). } \\
\text { 祖佛音觀 = Zü fü yĩn guān } \\
\text { memiliki arti Buddha Guan } \\
\text { Yin (Personal conversation, } \\
\text { Februari 2, 2017). } \\
\text { - Naga dalam budaya Jawa } \\
\text { melambangkan pelindung } \\
\text { (Sunaryo 103) }\end{array}$ \\
\hline
\end{tabular}

Pada bagian serambi terdapat pintu, leaky window, pilar, patung, tambur dan lonceng. Setiap elemen memiliki ornamen di dalamnya. (lihat gambar 5). Di bagian belakang tambur dan lonceng sebenarnya terdapat sepasang patung singa batu. 


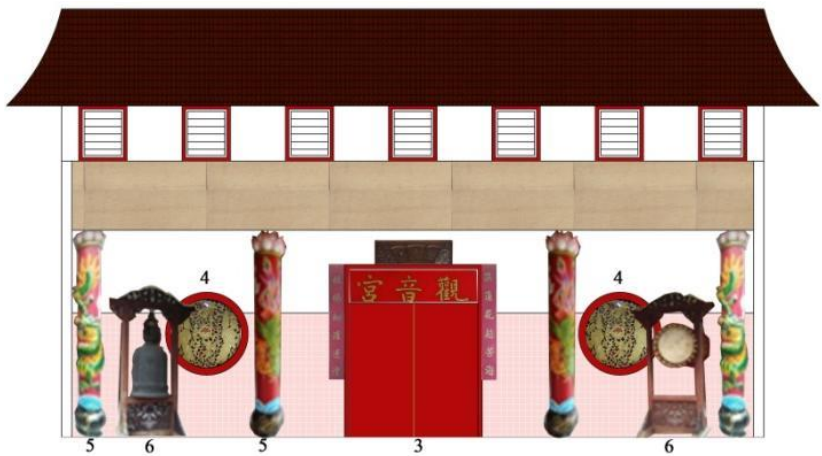

Gambar 5. Tampak serambi ruang sembahyang utama atau Kwan Im Thang.

Berikut tabel analisa pintu pada Ruang Sembayang Utama (lihat tabel 3)

Table 3. Analisa ornamen pada pintu ruang sembahyang utama.

\begin{tabular}{|c|c|c|}
\hline Ornamen & Tahap Pra-Ikonografi & Tahap Analisa Ikonografi \\
\hline 悹音很 & $\begin{array}{l}\text { Pada bagian atas bertuliskan } \\
\text { 宫音観, pada bagian kanan } \\
\text { pintu bertuliskan一朵蓮花超 } \\
\text { 苦 海 dan bagian kiri } \\
\text { bertuliskan 半枝楊柳度迷津. } \\
\text { Tulisan tersebut ditulis } \\
\text { dengan warna emas di atas } \\
\text { pintu kayu berwarna merah. }\end{array}$ & 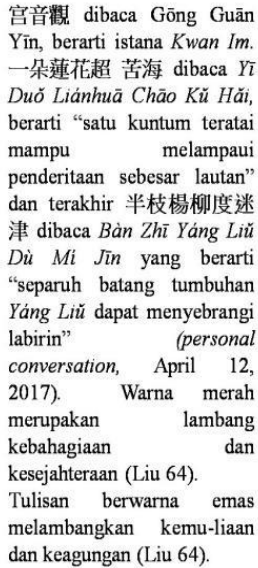 \\
\hline
\end{tabular}

Jendela pada ruang sembahyang utama biasa juga disebut dengan leaky window pada arsitektur Tionghoa. Berikut tabel analisa Jendela pada Ruang Sembayang Utama (lihat tabel 4)

Table 4. Analisa ornamen pada jendela ruang sembahyang utama

\begin{tabular}{|l|l|l|}
\hline Ornamen & \multicolumn{1}{|c|}{ Tahap Pra-Ikonografi } & Tahap Analisa Ikonografi \\
\hline 4. Leaky Window & $\begin{array}{l}\text { Jendela berbentuk geometis } \\
\text { lingkaran. Pada jendela } \\
\text { terdapat ornamen burung } \\
\text { phoenix, bunga-bungaan atau } \\
\text { tumbuhan, dan pada bagian } \\
\text { tengah tertulis 1951. Jendela } \\
\text { diberi warna merah untuk } \\
\text { framenya dan emas untuk } \\
\text { ukirannya. }\end{array}$ & $\begin{array}{l}\text { Phoenix merupakan lambang } \\
\text { dari kemakmuran, martabat, } \\
\text { dan kehormatan(Wen 25-26). } \\
\text { tamananan } 1951 \text { merupakan tahun } \\
\text { Fersonal conversation, } \\
\text { Warna merah melam- } \\
\text { bangkan kebahagiaan dan } \\
\text { kesejahteraan. Warna emas } \\
\text { melambangkan kemu-liaan } \\
\text { dan keagungan (Liu 64). }\end{array}$ \\
\hline
\end{tabular}

Pilar pada serambi terdapat 2 macam, pilar dengan ornamen burung phoenix yang berjumlah 2 dan pilar dengan ornamen naga berjumlah 6 . Berikut tabel analisa pilar pada Ruang Sembayang Utama (lihat tabel 5).
Table 5. Analisa ornamen pada pilar ruang sembahyang utama.

\begin{tabular}{|c|l|l|}
\hline Ornamen & \multicolumn{1}{|c|}{ Tahap Pra-Ikonografi } & TahapAnalisa Ikonografi \\
\hline 5. Phoenix dan Naga & $\begin{array}{l}\text { Pilar berbentuk silindris. } \\
\text { Terdapat 2 macam pilar pada } \\
\text { serambi, yang pertama } \\
\text { beromamen naga dan yang } \\
\text { satu lagi berornamen burung } \\
\text { phoenix. Kedua pilar } \\
\text { memiliki warna dasar } \\
\text { berwarna merah. }\end{array}$ & $\begin{array}{l}\text { Phoenix merupakan lambang } \\
\text { dari kemakmuran, martabat, } \\
\text { dan kehormatan(Wen 25-26). }\end{array}$ \\
$\begin{array}{l}\text { Naga keberuntungan, } \\
\text { keseimbangan dan } \\
\text { kemakmuran (Wen 15). } \\
\text { Selain itu juga bermakna } \\
\text { sebagai perlindungan (Wen } \\
\text { l6) Naga yang melilit/ } \\
\text { berlekuk ini melambangkan } \\
\text { kekuatan. }\end{array}$ \\
$\begin{array}{l}\text { Warna merah melam- } \\
\text { bangkan kebahagiaan dan } \\
\text { kesejahteraan (Liu 64). }\end{array}$ \\
\hline
\end{tabular}

Berikut tabel analisa tambur dan lonceng pada Ruang Sembayang Utama (lihat tabel 6)

Table 6. Analisa ornamen pada tambur dan lonceng ruang sembahyang utama.

\begin{tabular}{|c|l|l|}
\hline Ornamen & \multicolumn{1}{|c|}{ Tahap Pra-Ikonografi } & Tahap Analisa Ikonografi \\
\hline 6. Naga dan Mustika & $\begin{array}{l}\text { Pada tambur dan lonceng } \\
\text { terdapat ukiran yang } \\
\text { menggambarkan naga dan } \\
\text { mustika. }\end{array}$ & $\begin{array}{l}\text { Naga dan mustika } \\
\text { menyiratkan makna penge- } \\
\text { jaran akan ilmu sejati karena } \\
\text { mustika merupakan lambang } \\
\text { dari ilmu sejati dan } \\
\text { kebahagiaan (Yoswara, } \\
\text { Santosa, dan Haswanto 7). }\end{array}$ \\
\hline
\end{tabular}

Berikut tabel analisa patung singa batu pada Ruang Sembayang Utama (lihat tabel 7)

Table 7. Analisa ornamen pada patung singa batu ruang sembahyang utama.

\begin{tabular}{|c|l|l|}
\hline Ornamen & Tahap Pra-Ikonografi & Tahap Analisa Ikonografi \\
\hline Patung singa batu & $\begin{array}{l}\text { Pada patung yang sebelah } \\
\text { kiri terdaat anak di bawa } \\
\text { kakiny dan patung di } \\
\text { sebelah kanan terdapat bola } \\
\text { dunia di bawah kakinya } \\
\text { Patung ini difinishing dengan } \\
\text { warna emas. }\end{array}$ & $\begin{array}{l}\text { Dalam ajaran Buddha, } \\
\text { binatang ini merupakan } \\
\text { lambang dari penegak hukum } \\
\text { dan pelindung bangunan suci. } \\
\text { Selain itu juga lambang dari } \\
\text { otoritas (Lillian 251). } \\
\text { Anak di bawah kakinya } \\
\text { melambangkan kebahagiaan } \\
\text { dan bola dibawah kakinya } \\
\text { yang melambangkan kesa- } \\
\text { tuan seluruh negeri (Williams } \\
\text { 252). } \\
\text { Warna emas melambangkan } \\
\text { kemuliaan dan keagungan } \\
\text { (Liu 64). }\end{array}$ \\
\hline
\end{tabular}

\section{B. Pendopo}

Pendopo adalah area yang dibangun pada tahun 1951 yang digunakan sebagai fasilitas duduk bagi jemaat dan pengunjung Vihara. (lihat gambar 6)

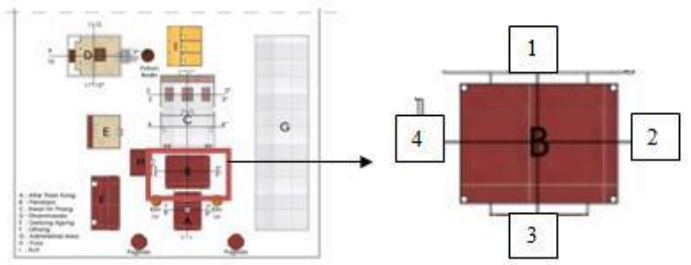

Gambar 6. Layout ruang sembahyang utama (kiri) dan layout pendopo (kanan)

Pada area pendopo ini ornamen yang dapat ditemukan adalah kaligrafi China. Berikut tabel analisa kaligrafi pada sisi utara dan sisi timur gedung Pendopo (lihat tabel 8) 
Table 8. Analisa kaligrafi pada sisi utara dan timur gedung Pendopo.

\begin{tabular}{|c|c|c|}
\hline Ornamen & Tahap Pra-Ikonografi & TahapAnalisa Ikonografi \\
\hline 1. Kaligrafi & $\begin{array}{l}\text { Terletak pada plafon sisi } \\
\text { utara. Tertulis dari kanan ke } \\
\text { kiri 濁五清 香五奉 (Fèng } \\
\text { Wũ Xiāng Qìng Wü Zhuó) }\end{array}$ & $\begin{array}{l}\text { "Memberi penghormatan } \\
\text { dengan lima dupa mem- } \\
\text { bersihkan lima kekeruhan". } \\
\text { (Personal coversation, April } \\
18,2017 \text { ) }\end{array}$ \\
\hline 2. Kaligrafi & $\begin{array}{l}\text { Terletak pada plafon sisi } \\
\text { timur. Tertulis 天西 花雨 } \\
\text { (Tiānxī Huā Yü). }\end{array}$ & $\begin{array}{l}\text { "Hujan bunga nirwana" } \\
\text { (Personal communication, } \\
\text { April 18, 2017) }\end{array}$ \\
\hline 3. Kaligrafi & $\begin{array}{l}\text { Terletak pada plafon sisi } \\
\text { selatan. Tertulis dari kanan } \\
\text { ke kiri正六根 得六通 atau } \\
\text { zhèng liù Gēn Dé liù Tōng }\end{array}$ & $\begin{array}{|lcc|}\text { "Meluruskan } & 6 & \text { akar } \\
\text { mendapat } & 6 & \text { pengertian" } \\
\text { (Personal } & \text { coversation, April } \\
18,2017) & & \end{array}$ \\
\hline 4. Kaligrafi & $\begin{array}{l}\text { Terletak pada plafon sisi } \\
\text { barat. Tertulis海南薰風 atau } \\
\text { Hăi Nán XüüFêng }\end{array}$ & $\begin{array}{l}\text { "Aroma wangi bunga oleh } \\
\text { angin laut Cina selatan" } \\
\text { (Personal conversation, April } \\
18,2017)\end{array}$ \\
\hline
\end{tabular}

\section{Dhamasala}

Gedung Dhamasala di bangun pada tahun 1967 dan direnovasi pada tahun 2010. Ornamennya teraplikasi pada dinding, jendela, pintu, dan plafon. Ornamen-ornamen yang digunakan adalah ornamen yang umumnya berkaitan dengan ajaran Buddha. (lihat gambar 7 dan 8)

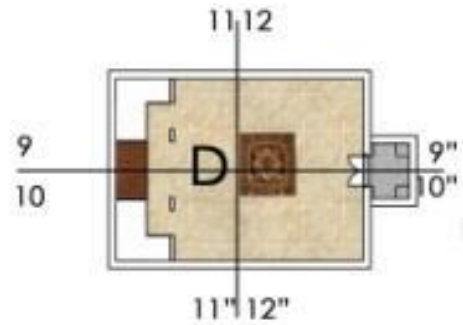

Gambar 7. Layout gedung Dhamasala.
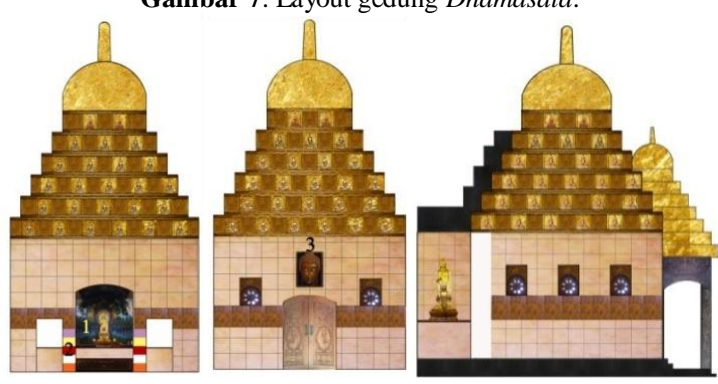

Gambar 8. Potongan 11-11” (kiri), Potongan 12-12” (tengah), Potongan 99" (kanan)

Pintu yang digunakan pada ruang dhamasala merupakan pintu kayu ukir jepara yang di-finishing natural sehingga menampilkan warna kayu aslinya. Berikut tabel analisa pintu pada gedung dharmasala (lihat tabel 9)

Table 9. Analisa pintu pada gedung dhamasala

\begin{tabular}{|l|l|l|}
\hline \multicolumn{1}{|c|}{ Ornamen } & \multicolumn{1}{|c|}{ Tahap Pra-Ikonografi } & TahapAnalisa Ikonografi \\
\hline $\begin{array}{l}\text { Swastika, Dharmacakra, } \\
\text { Peony dan Magpie. }\end{array}$ & $\begin{array}{l}\text { Pintu terbuat dari material } \\
\text { kayu yang kemudian diukir } \\
\text { dengan ornamen. Ornamen } \\
\text { yang terukir pada pintu } \\
\text { adalah swastika, dharma- } \\
\text { cakra, peony dan magpie. }\end{array}$ & $\begin{array}{l}\text {-Swastika menandakan kebe- } \\
\text { runtungan (Herlina 19). } \\
\text {-Dharmacakra adalah repr- } \\
\text { esentasi dari simbol pemu- } \\
\text { taran roda dharma (Herlina } \\
\text { 20). } \\
\end{array}$ \\
& & $\begin{array}{l}\text {-Bunga Peony melam- } \\
\text { bangkan kekayaan dan } \\
\text { kehormatan (Wen 46). } \\
\text {-Magpie adalah lambang dari } \\
\text { "bird of joy" (Williams 259). }\end{array}$ \\
\hline
\end{tabular}

Pada dinding gedung dhamasala terdapat beberapa ornamen seperti relief, bender Buddhis, dan lukisan. Berikut tabel analisa ornamen dinding pada gedung dharmasala (lihat tabel 10)

Table 10. Analisa ornanen pada dinding gedung dhamasala.

\begin{tabular}{|c|c|c|}
\hline Ornamen & Tahap Pra-Ikonografi & Tahap Analisa Ikonografi \\
\hline 1. Relief & $\begin{array}{l}\text { Terletak dibelakang patung } \\
\text { Buddha, berbentuk pohon } \\
\text { Bodhi dan Aura Buddha. }\end{array}$ & $\begin{array}{l}\text { Pohon Bodhi meru-pakan } \\
\text { tempat di mana Buddha } \\
\text { Gautama mencari } \\
\text { pencerahan (Williams 70). } \\
\text { Aura Buddha adalah warna } \\
\text { tubuh Buddha yang muncul } \\
\text { ketika mencapai pencerahan. }\end{array}$ \\
\hline 2. Bendera Buddhist & $\begin{array}{l}\text { Terdiri dari } 5 \text { warna yaitu, } \\
\text { biru, kuning, merah, putih, } \\
\text { dan jingga. }\end{array}$ & $\begin{array}{l}\text { Biru (Nila) dari warna } \\
\text { rambut sang Buddha melam- } \\
\text { bangkan bhakti dan pengab- } \\
\text { dian. } \\
\text { Kuning emas (Pita) berasal } \\
\text { dari warna kulit sang Buddha } \\
\text { dan melambangkan kebijak- } \\
\text { sanaan. } \\
\text { Merah (Lohita) berasal dari } \\
\text { darah sang Buddha yang } \\
\text { melambangkan cinta kasih. } \\
\text { Putih (Odata) berasal dari } \\
\text { tulang dan gigi sang Buddha } \\
\text { melam-bangkan kesucian. } \\
\text { Jingga (Manjettha) berasal } \\
\text { dari telapak tangan, kaki, dan } \\
\text { bibir yang melambangkan } \\
\text { semangat (Herlina 18) }\end{array}$ \\
\hline 3. Lukisan & \begin{tabular}{|lrr} 
Lukisan & \multicolumn{2}{c}{ memvisualkan } \\
gambar & wajah & Buddha \\
berwarna & emas & dengan \\
background hitam. &
\end{tabular} & $\begin{array}{l}\text { Buddha Gautama adalah } \\
\text { pelopor lahirnya agama } \\
\text { Buddha (Sudharma 1). } \\
\text { Buddha keluar meninggalkan } \\
\text { rumah dan keluarganya untuk } \\
\text { mencari "pencerahan" pada } \\
\text { usia } 30 \text { tahun (Bodhi 8,10). } \\
\text { Warna emas melambangkan } \\
\text { kemuliaan dan keagungan } \\
\text { (Liu 64). Sedangkan warna } \\
\text { hitam melambangkan kebai- } \\
\text { kan (Lilian, 146). }\end{array}$ \\
\hline
\end{tabular}

Plafon gedung dhamasala ini memiliki keunikan. Keunikan tersebut terinspirasi dari candi Borobudur, dimana pada tingkat 1-4 dihiasi arca yang terdapat pada plafon berbeda-beda mudranya di setiap sisi. Kemudian pada tingkat ke 5 dan ke 6 juga memiliki mudra yang berbeda. Semua arca berwana emas (lihat gambar 9)

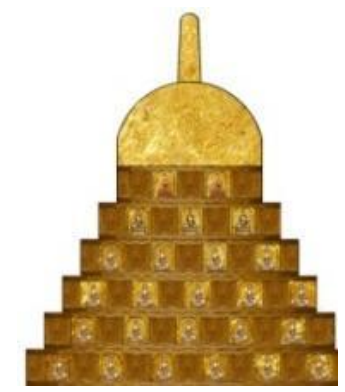

Gambar 9. Plafon pada gedung Dhamasala dengan ornamen arca Buddha di dalamnya

Berikut tabel analisa ornamen pada plafon gedung dharmasala (lihat tabel 11) 
Table 11. Analisa plafon pada gedung dhamasala.

\begin{tabular}{|c|c|c|}
\hline Ornamen & Tahap Pra-Ikonografi & Tahap Analisa Ikonografi \\
\hline Dhyana Mudra & $\begin{array}{l}\text { Terletak pada tingkat pertama } \\
\text { hingga keempat di sisi barat. }\end{array}$ & $\begin{array}{lrr}\text {-Dhyana mudra } & \text { meng } \\
\text { gambarkan posisi } & \text { semedi } \\
\text { (Miksic 54). } & & \end{array}$ \\
\hline BhumiparsaMudra & $\begin{array}{l}\text { Terletak pada tingkat pertama } \\
\text { hingga keempat di sisi timur. }\end{array}$ & $\begin{array}{l}\text { Bhumiparsa mudra melam } \\
\text { bangkan saat sang Buddha } \\
\text { memanggil Dewi Bumi } \\
\text { sebagai saksi ketika dia } \\
\text { menangkis serangan iblis } \\
\text { Mara (Miksic 54). }\end{array}$ \\
\hline Abhaya Mudra & $\begin{array}{l}\text { Terletak pada tingkat pertama } \\
\text { hingga keempat di sisi utara. }\end{array}$ & $\begin{array}{l}\text { Abhaya mudra meng } \\
\text { gambarkan sikap tenang dan } \\
\text { tidak gentar (Miksic }\end{array}$ \\
\hline Vara Mudra & \begin{tabular}{l}
\multicolumn{3}{c}{ Terletak pada tingkat pertama } \\
hingga keempat di sisi \\
selatan.
\end{tabular} & $\begin{array}{l}\text { Vara mudra melam-bangkan } \\
\text { pemberian amal (Miksic 54). }\end{array}$ \\
\hline Vitarka Mudra & $\begin{array}{l}\text { Terletak pada semua sisi pada } \\
\text { tingkat kelima. }\end{array}$ & $\begin{array}{lr}\text { Vitarka } & \text { melambangkan } \\
\text { pemberian } & \text { pengajaran } \\
\text { (Miksic 54). } & \end{array}$ \\
\hline DharmacakraMudra & $\begin{array}{l}\text { Terletak pada semua sisi pada } \\
\text { tingkat keenam. }\end{array}$ & $\begin{array}{l}\text { Dharmacakra memutar roda } \\
\text { dharma (Miksic 54). } \\
\text { Warna emas melambangkan } \\
\text { kemuliaan dan keagungan } \\
\text { (Liu 64). }\end{array}$ \\
\hline
\end{tabular}

Berikut tabel analisa ornamen pada jendela gedung dharmasala (lihat tabel 12)

Table 12. Analisa jendela pada gedung dhamasala.

\begin{tabular}{|c|c|c|}
\hline Ornamen & Tahap Pra-Ikonografi & Tahap Analisa Ikonografi \\
\hline Dharmacakra & $\begin{array}{l}\text { Jendela berbentuk geometris } \\
\text { persegi panjang yang } \\
\text { didalamnya berornamen } \\
\text { dharmacakra. Jendela di- } \\
\text { finishing berwarna emas }\end{array}$ & $\begin{array}{l}\text {-Dharmacakra adalah repre- } \\
\text { sentasi dari simbol pemu- } \\
\text { taran roda dharma (Herlina } \\
\text { 20). } \\
\text { Warna emas melambangkan } \\
\text { kemuliaan dan keagungan } \\
\text { (Liu 64). }\end{array}$ \\
\hline
\end{tabular}

Kolom yang terlihat terdapat pada serambi gedung (lihat gambar 8.). Pada kolom tersebut terdapat ornamen naga dan bagian atasnya dapat ditemukan ornamen kala. Ornamen kala ini biasa ditemukan pada candi-candi dan Vihara menggunakan ornamen ini karena gedung dhamasala didesain dengan candi Mendut dan candi Borobudur sebagai inspirasinya. Berikut tabel analisa ornamen pada kolom gedung dharmasala (lihat tabel 13)

Table 13. Analisa kolom pada gedung dhamasala.

\begin{tabular}{|c|l|l|}
\hline Ornamen & \multicolumn{1}{|c|}{ Tahap Pra-Ikonografi } & \multicolumn{1}{|c|}{ Tahap Analisa Ikonografi } \\
\hline Naga dan Kala & $\begin{array}{l}\text { Kolom pada serambi dihiasi } \\
\text { dengan ornamen naga dan } \\
\text { kala pada bagian atasnya. }\end{array}$ & $\begin{array}{l}\text {-Kala memiliki fungsi } \\
\text { spiritual sebagai "tolak bala" } \\
\text { (Sunaryo 50). } \\
\text { Naga dalam budaya } \\
\text { Tionghoa melam-bangkan } \\
\text { keberuntungan, keseim- } \\
\text { bangan dan kemakmuran } \\
\text { (Wen 15). Selain itu juga } \\
\text { bermakna sebagai } \\
\text { perlindungan (Wen 16) }\end{array}$ \\
\hline 3. & & \\
\hline
\end{tabular}

\section{Gedung Altar Thian Kong}

Gedung ini dibangun pada tahun 2012 dengan berbagai ornamen yang kental dengan budaya Tionghoa. Gedung ini merupakan gedung area terbuka sehingga tidak terdapat dinding pada sisi-sisinya. Pada gedung ini ornamen teraplikasi pada seluruh pilar, plafon, dan altar sembahyangnya. Bentuk ornamen yang diaplikasikan bervariasi seperti naga, phoenix, kuncup teratai, dan sulur.

Berikut tabel analisa ornamen pada pilar gedung altar Thian Kong (lihat tabel 14)

Table 14. Analisa pilar pada gedung altar Thian Kong.

\begin{tabular}{|c|c|c|}
\hline Ornamen & Tahap Pra-Ikonografi & Tahap Analisa Ikonografi \\
\hline \multirow{2}{*}{ Naga dan awan } & \multirow[t]{2}{*}{$\begin{array}{l}\text { Pilar berbentuk } \\
\text { dengan warna dindris } \\
\text { warna merah. } \\
\text { berbentuk awan dan naga } \\
\text { yang melilit pilar. }\end{array}$} & $\begin{array}{|lr|}\text {-Naga yang } & \text { melilit/ } \\
\text { berlekuk } & \text { ini } \\
\text { melambangkan } & \text { kekuatan } \\
\text { Naga } & \text { keberuntungan, } \\
\text { keseimbangan } & \text { dan } \\
\text { kemakmuran (Wen } & 15) \text {. } \\
\text { Selain itu juga } & \text { bermakna } \\
\text { sebagai perlindungan (Wen } \\
\text { 16). }\end{array}$ \\
\hline & & $\begin{array}{l}\text {-Awan atau ruyi, lambang } \\
\text { penghargaan dan kegem- } \\
\text { biraan serta lambang permo- } \\
\text { honan akan kesuksesan (Wen } \\
98-99 \text { ). } \\
\text {-Warna merah yang melam- } \\
\text { bangkan kegembiraan dan } \\
\text { kesejahteraan (Liu 64). }\end{array}$ \\
\hline
\end{tabular}

Perabot pada gedung altar ini ada dua yaitu meja untuk sembahyang dan hio lo yang digunakan untuk menancapkan dupa. Berikut tabel analisa perabotr gedung altar Thian Kong (lihat tabel 15)

Table 15. Analisa perabot pada gedung altar Thian Kong.

\begin{tabular}{|c|c|c|}
\hline Ornamen & Tahap Pra-Ikonografi & Tahap Analisa Ikonografi \\
\hline $\begin{array}{l}\text { Naga dan phoenix } \\
\text { REFit. }\end{array}$ & $\begin{array}{l}\text { Ornamen yang teraplikasi } \\
\text { pada salah satu sisi meja dan } \\
\text { hio lo adalah ornamen naga. } \\
\text { Sedangkan disisi lain meja } \\
\text { juga teraplikasi ornamen lain } \\
\text { yaitu ornamen phoenix. } \\
\text { Ornamen difinishing dengan } \\
\text { warna emas dan meja di } \\
\text { finishing dengan warna hitam }\end{array}$ & $\begin{array}{l}\text {-Naga dalam budaya } \\
\text { Tionghoa melam-bangkan } \\
\text { keberuntungan, keseim- } \\
\text { bangan dan kemakmuran } \\
\text { (Wen 15). Selain itu juga } \\
\text { bermakna sebagai } \\
\text { perlindungan (Wen 16) } \\
\text {-Phoenix melambangkan } \\
\text { kemakmuran, martabat, dan } \\
\text { kehormatan (Wen 25-26). } \\
\text {-Warna emas melambangkan } \\
\text { kemuliaan dan keagungan } \\
\text { (Liu 64). Sedangkan warna } \\
\text { hitam melambangkan } \\
\text { kebaikan (Lilian, 146). }\end{array}$ \\
\hline
\end{tabular}

Pada plafon ornamen yang teraplikasi adalah sulur, kuncup teratai, naga, pedang, dan kipas.(lihat gambar 10 dan tabel 16)

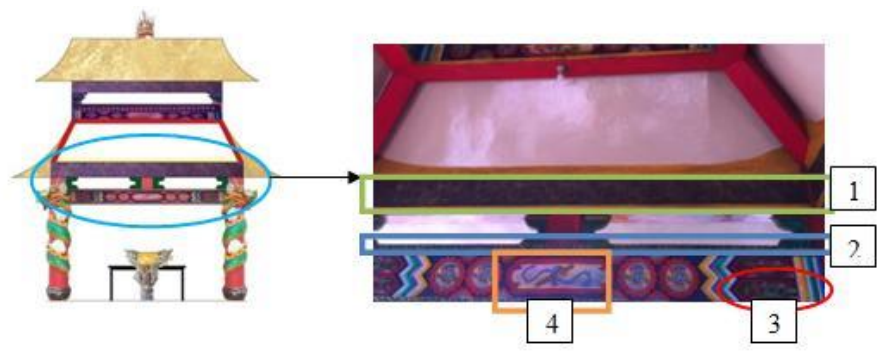

Gambar 10. Tampak potongan gedung altar Thian Kong(kiri) dan detail keterangan ornamen pada plafon (kanan)

Berikut tabel analisa ornamen pada kolom gedung Altar Thian Kong (lihat tabel 16) 
Table 16. Analisa plafon pada gedung altar Thian Kong.

\begin{tabular}{|l|l|l|}
\hline \multicolumn{1}{|c|}{ Ornamen } & \multicolumn{1}{|c|}{ Tahap Pra-Ikonografi } & \multicolumn{1}{|c|}{ Tahap Analisa Ikonografi } \\
\hline 1. Sulur & $\begin{array}{l}\text { Ornamen sulur ini diberi } \\
\text { finishing bronze dengan } \\
\text { tampilan sedikit glossy. }\end{array}$ & $\begin{array}{l}\text {-Sulur merupakan lambang } \\
\text { keabadian dan kemakmuran } \\
\text { (Wen 53). }\end{array}$ \\
\hline 2. Kuncup Teratai & $\begin{array}{l}\text { Dalam ornamen kuncup } \\
\text { teratai ini juga terdapat sulur- } \\
\text { suluran. Ornamen } \\
\text { diaplikasikan dengan diukir } \\
\text { sehingga terkesan timbul. }\end{array}$ & $\begin{array}{l}\text { Bunga teratai yang belum } \\
\text { mekar melambangkan kebi- } \\
\text { jaksanaan Sang Buddha } \\
\text { (Cooper 101). }\end{array}$ \\
\hline 3. Naga & $\begin{array}{l}\text { Ornamen naga yang } \\
\text { diaplikasikan pada plafon } \\
\text { gedung ini diberi finishing } \\
\text { dengan warna hijau dan } \\
\text { terdapat awan-awan } \\
\text { disekitarnya. }\end{array}$ & $\begin{array}{l}\text { Naga kekuatan, kebe-ranian, } \\
\text { kewaspadaan, keamanan, dan } \\
\text { penjaga barang-barang suci } \\
\text { serta simbol yang melam- } \\
\text { bangkan penolak roh jahat } \\
\text { (Lilian 150). }\end{array}$ \\
\hline 4. Pedang dan Kipas & $\begin{array}{l}\text { Pedang diaplikasikan pada } \\
\text { sisi utara dan selatan } \\
\text { sedangkan kipas diapli- } \\
\text { kasikan pada sisi timur dan } \\
\text { barat. }\end{array}$ & $\begin{array}{l}\text { Pedang yang melambangkan } \\
\text { kebijaksanaan dan wawasan } \\
\text { yang dalam (Williams 366). } \\
\text { Kipas melambangkan kehar- } \\
\text { monisan dan kebahagiaan } \\
\text { (Williams 167). }\end{array}$ \\
\hline
\end{tabular}

\section{E. Vihara Avalokitesvara Pamekasan, Madura}

Berikut diagram analisa Vihara Avalokitesvara Pamekasan, Madura (lihat Diagram 1)

Diagram 1. Diagram Interpretasi Ikonologi Vihara Avalokitesvara Pamekasan, Madura

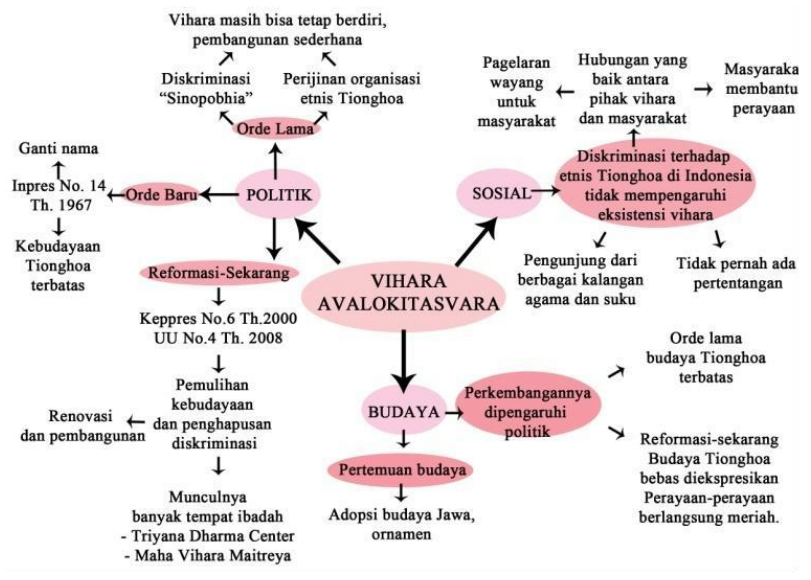

1. Analisa Politik

Pada pemerintahan Presiden Soekarno, diskriminasi terhadap etnis Tionghoa masih belum bisa terhapuskan. Hal tersebut tercermin dalam beberapa kebijakan seperti masalah kepemilikan tanah oleh peranakan Tionghoa sebagai warisan dari ibunya yang pribumi diambil pemerintah dan pada tahun 1953 adanya kebijakan pemerintah mengenai RUU Kewarganegaraan yang menyulitkan warga Tionghoa. Kemudian pada tahun 1959 Presiden Soekarno menandatangani Peraturan Pemerintah No.10 yang berisi mengenai larangan bagi orang-orang asing (khususnya orang Tionghoa) untuk berdagang eceran di daerah-daerah pedalaman [6]. Namun walaupun demikian, Soekarno masih memberi kelonggaran dengan mengijinkan berdirinya organisasiorganisasi politik dan sosial bagi masyarakat Tionghoa seperti Partai Demokrasi Tionghoa Indonesia (PDTI) dan Perhimpunan Buddhis Indonesia (PERBUDHI). Sehingga pada masa pemerintahan Soekarno pihak Soekarno dapat melakukan renovasi secara sederhana.
Pada pemerintahan Orde Baru, diskriminasi terhadap etnis Tionghoa semakin buruk. Kondisi tersebut dipicu oleh keluarnya Inpres Nomor 14 Tahun 1967 yang didalamnya melarang beberapa hal sebagai berikut [7]:

- Aturan penggantian nama.

- Melarang segala bentuk penerbitan dengan bahasa serta aksara China. Larangan penggunaan bahasa Mandarin dalam berkomunikasi di depan umum dalam bentuk apapun.

- Membatasi kegiatan-kegiatan keagamaan hanya dalam keluarga.

- Tidak mengizinkan pagelaran dalam perayaan hari raya tradisional Tionghoa di muka umum.

- Melarang sekolah-sekolah Tionghoa dan menganjurkan anak-anak Tionghoa untuk masuk ke sekolah umum negeri atau swasta.

Akibat dikeluarkannya peraturan tersebut kebudayaan Tionghoa di Indonesia mengalami kelumpuhan. Aturan pergantian nama menyebabkan Vihara Avalokitesvara berubah nama. Awalnya Vihara ini bernama Kwan Im Kiong namun akibat kebijakan tersebut nama tersebut diganti dengan Vihara Avalokitesvara seperti sekarang ini. Dampak lain yang dirasakan adalah pembatasan kebudayaan Tionghoa. Perayaan-perayaan seperti Imlek dan pertunjukan tari-tarian hanya dilakukan didalam Vihara saja.

Setelah Presiden Soeharto lengser, diskriminasi terhadap etnis Tionghoa mulai memudar sejak Presiden K.H Abdurahmanwahid mengeluarkan Keppres Nomor 6 Tahun 2000 yang mencabut Inpres Nomor 14 tahun 1967.Berkat pencabutan Inpres tersebut etnis Tionghoa beserta kebudayaannya bisa merasakan kebebasan untuk mengekspresikan eksistensinya. Hal tersebut diperkuat dengan dikeluarkannya UU No.40/2008 tentang Penghapusan Diskriminasi Ras dan Etnis (PDRE) pada masa pemerintahan Presiden Susilo Bambang Yudhoyono. Dampak bagi Vihara adalah, pihak Vihara dapat membangun maupun merenovasi Vihara dengan berbagai ornamen yang kental dengan budaya Tionghoa.

\section{Analisa Sosial}

Di tengah diskriminasi terhadap etnis Tionghoa yang terjadi di Indonesia, namun keberadaan Vihara Avalokitesvara di Pamekasan mampu diterima masyarakat sekitar. Dalam perjalanannya, Vihara ini tidak pernah mengalami pertentangan baik dari masyarakat sekitar maupun [8].

Keberadaan Vihara ini dikenal dengan kerukunan antar umat beragamanya. Hal tersebut terbukti bahwa didalam Vihara ini tidak hanya memfasilitasi umat Buddha, KongHucu, dan Tao untuk beribadah namun juga ada Musholla dan Pura. Keberadaan musholla menjadi bukti kepedulian pengurus Vihara terhadap masyarakat sekitar dan para pekerja akan kebutuhan musholla sebagai tempat ibadah. Masyarakat Madura pada umumnya merupakan pemeluk agama Islam [3]. Selain itu saat ini Vihara Avalokitesvara ramai dikunjungi 
oleh berbagai kalangan, dan tak sedikit yang beragama muslim oleh karena itu Vihara mempertahankan keberadaan musholla tersebut.

Selain adanya mushola didalam Vihara juga terdapat Pura yang diperuntukan bagi umat Hindu. Pura ini dibangun pada tahun 1985. Semua umat baik Buddha, Islam, Hindu, Khonghucu dan Tao dapat hidup berdampingan ketika Vihara mengadakan perayaan keagamaan Budha, umat Islam selalu berbaur ke dalam perayaan tersebut. Tidak sedikit diantara mereka yang menjadi panitia kegiatan yang diselenggarakan pihak yayasan.

\section{Analisa Budaya}

Pada pemerintahan Presiden Soekarno etnis Tionghoa di Indonesia masih mengalami diskriminasi, namun ditengah diskriminasi tersebut masih terdapat kelonggaran dalam kebebasan mengekspresikan kebudayaan Tionghoa juga masih diberikan pada masa pemerintahan Presiden Soekarno.Hal itu dapat terlihat dari pementasan barongsai yang masih diperbolehkan. Presiden Soekarno mengeluarkan Penetapan Pemerintah tentang hari-hari raya umat beragama Nomor 2/OEM-1946. Pada Pasal 4 peraturan itu menyebut tahun baru Imlek, hari wafatnya Khonghucu. Ceng Beng, dan hari lahirnya Khonghucu sebagai hari libur. Pada masa pemerintahan Presiden Soekarno Vihara masih menggunakan nama Kwan Im Kiong sebagai identitas dan perayaan kebudayaan Tionghoa masih dapat bebas dipertunjukan.

Pada masa orde baru berbagai diskriminasi terhadap etnis Tionghoa bermunculan. Dikeluarkannya Inpres Nomor 14 Tahun 1967 membatasi berbagai kebudayaan Tionghoa untuk dapat diekspresikan dimuka umum seperti pertunjukan barongsai dilarang ditunjukan dimuka umum [7]. Vihara Avalokitesvara Pamekasan pada masa itu juga tidak berani menampilkan pertunjukan barongsai maupun perayaan kebudayaan Tionghoa lainnya pertunjukan dilakukan di dalam Vihara [8] Dampak lainnya adalah ketika pembangunan gedung dhamasala, Vihara tidak menampilkan sama sekali ornamen yang berbau budaya Tionghoa serta melakukan penggantian nama sebagai identitasnya.

Setelah masa orde baru berlalu, kebijakan mengenai pembatasan keagamaan dan kebudayaan Tionghoa dihapuskan oleh Presiden K.H. Abdurrahman Wahid atau Gus Dur mencabut Inpres Nomor 14 Tahun 1967 dengan menerbitkan Keppres Nomor 6 Tahun 2000. Hal tersebut menjadi tonggak kebangkitan kembali kebudayaan Tionghoa di Indonesia.Terlebih pada pemerintahan SBY dikeluarkannya UU No.40/2008 tentang Penghapusan Diskriminasi Ras dan Etnis (PDRE) memberi kebebasan terhadap kebudayaan Tionghoa.Vihara dapat membangun dengan berbagai ornamen yang identik dengan budaya Tionghoa. (lihat gambar 11)

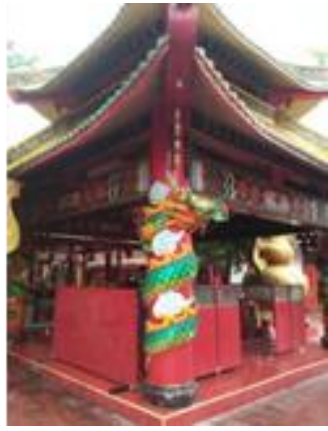

Gambar 11. Tampak gedung altar Thian Kong

Perayaan-perayaan kebudayaan Tionghoa diijinkan pemerintah. Pada Vihara Avalokitesvara sendiri juga melakukan berbagai pementasan barongsai. Pada tahun 2012, pementasan barongsai dilakukan dengan dihadiri umat Buddha se-Indonesia. Perayaan tersebut juga diikuti dengan pagelaran wayang kulit pada malam harinya.

Perayaan kebudayaan yang dilakukan secara bersamaan menunjukan toleransi budaya antara budaya lokal dan budaya Tionghoa. Pelaksanaan pagelaran wayang di Vihara Avalokitesvara. Pagelaran wayang di Vihara ini bukan hanya berfungsi sebagai upacara ritual, tradisi, maupun sosial namun sebagai bentuk pencampuran kebudayaan. Hal tersebut juga tercermin dengan adanya langgar yang difungsikan sebagai musholla dan merupakan adopsi dari rumah tradisional Madura.

\section{SIMPULAN}

Berdasarkan tahap pertamaornamen pada gedung Kwan Im Thang adalah ornamen-ornamen berupa hewan seperti naga Chinadan naga Jawa, phoenix, ornamen tumbuhan berupa teratai dan sulur, simbol Buddhisme berupa swastika dan kaligrafi China.Pada pendopo ornamen-ornamennya berupa kaligrafi.Pada Dhamasala ornamen hewan berupa naga, tumbuhan berupa teratai, simbol Buddhisme berupa dharmacakra dan swastika.Pada Altar Thian Kong hanya digunakan ornamen hewan dan tumbuhan berupa naga dan teratai serta sulur.Di tahap kedua diketahui bahwa ornamen naga China melambangkan kekuatan, phoenix kemakmuran dan kehormatan.Teratai melambangkan kemurnian, sedangkan sulur lambang kemakmuran. Swastika sebagai simbol kebaikan, dan dharmacakra lambang ajaran roda dharma Buddha. Sedangkan kaligrafi mengandung arti ajaran-ajaran dalam agama Buddha.

Berdasarkan interpretasi ikonologi, Vihara diinterpretasi dalam segi politik, sosial dan budaya disimpulkan bahwa vihara ini dapat bertahan dan berkembang sampai sekarang, bahkan mampu bertemu dan bersanding dengan kebudayaan lain karena dari segi politik terdapat kebijakan-kebijakan yang menghapuskan diskriminasi terhadap etnis Tionghoa sekaligus dengan kebudayaan dan kepercayaannya. Sehingga secara sosial masyarakat lebih mudah menerima adanya vihara ini. 


\section{REFERENSI}

[1] Hartono, R. 2006. Vihara Di Jogjakarta Landasan Konseptual Perancangan Tugas Akhir. Undergraduate thesis, Duta Wacana Christian University

[2] Fittrya, Laylatul. 2013. Tionghoa Dalam Diskriminasi Orde Baru Tahun 1967-2000”. Avatara Vol.1 No.2 (Mei 2013):160

[3] Rifai, Mien A., \& Nurinwa Ki S. Hendrowinoto. 1991 Mohammad Noer. Jakarta: Yayasan Biografi Indonesia.

[4] Kartodirdjo, Sartono, et al. 1993, 700 Tahun Majapahit: (1293-1993) Suatu Bunga Rampai Edisi 2. Surabaya: Dinas Pariwisata Jawa Timur. 1993.

[5] Panofsky, Erwin. 1955, Meaning In The Visual Art. The university of Chicago Press. 1955

[6] Setiono, Benny G. 2003. Tionghoa dalam Pusaran Politik. Jakarta: Elkasa

[7] Suryadinata, Leo. 2002. Negara dan Etnis Tionghoa. Jakarta : LP3ES.

[8] Wawancara Personal. Mahinda Kosala. Februari-Mei 2017. 